This paper has to be cited as: Martínez-Ibáñez, V., Garrido, M.E., Hidalgo Signes, C. \& Tomás, R. 2021. Micro and macro-structural effects of high temperatures in Prada limestone: Key factors for future fireintervention protocols in Tres Ponts Tunnel (Spain). Construction and Building Materials, 286, 122960, doi: https://doi.org/10.1016/j.conbuildmat.2021.122960. The final publication is available at Elsevier via: https://www.sciencedirect.com/science/article/abs/pii/S0950061821007200

\title{
Micro and macro-structural effects of high temperatures in Prada limestone: Key factors for future fire-intervention protocols in Tres Ponts Tunnel (Spain)
}

\author{
Martínez-Ibáñez, V., Garrido, M.E., Hidalgo Signes, C. \& Tomás, R.
}

\begin{abstract}
Temperature and cooling methods strongly affect the stability of tunnels drilled in rock masses and so condition interventions for fire emergencies. Samples from two horizontal boreholes drilled in 'Prada' limestone during the design stage of the Tres Ponts Tunnel in the Catalan south Pyrenean zone (Spain) are heated from 105 to $600^{\circ} \mathrm{C}$, and subsequently cooled with air or water to simulate fire extinguishing interventions. Changes in chemical composition and microstructure, physical properties (open porosity, volume, dry total weight, P and S-wave velocity), and mechanical properties (uniaxial compressive strength, elastic modulus, and Poisson's ratio) are analysed. Rock weakening is observed even at low temperatures $\left(T<300^{\circ}\right.$ $\mathrm{C})$. The influence of the cooling method appeared at intermediate temperatures of $300-400^{\circ} \mathrm{C}$ and open porosity, P and S-wave velocities, and elastic modulus show greater variation for water-cooled samples. A temperature of $500^{\circ} \mathrm{C}$ is of paramount importance for 'Prada' limestone as it leads to a dramatic increase in porosity and a notable decrease in $\mathrm{P}$ and S-wave velocities under both cooling methods. Trans-granular micro-crack progression is observed at $500^{\circ} \mathrm{C}$ using scanning electron microscope (SEM), and water-cooled samples show a greater loss in uniaxial compressive strength (UCS), and this is due to micro-crack connections and growing fissures. Thermal damage at $600^{\circ} \mathrm{C}$ is also greater when samples are quickly cooled. An ANOVA and a simple regression analysis are performed to discard the influence of the natural location of the borehole samples in the obtained experimental results. Finally, correlations to predict UCS and elastic modulus from volume, open porosity, and P-wave velocity after thermal treatment are proposed using simple exponential and potential functions to help make preliminary decisions after a tunnel fire. These predictive results on the effects of fire on Prada limestone will be considered for the definition of future fire intervention protocols in the Tres Ponts Tunnel.
\end{abstract}

Keywords: thermal damage; physical and mechanical properties; cracks; tunnel fire; limestone; correlations 


\section{Introduction}

Vehicle fires in road tunnels are not very rare events and their consequences may be far greater than fires in open spaces [1]. The extreme events that occurred in the Mont Blanc Tunnel (France-Italy 1999), the Tauern Tunnel (Austria 1999) [2], and the Gotthard Tunnel (Switzerland 2001) dominated discussion of tunnel fires in the early $21^{\text {st }}$ century and gave rise to international regulations and recommendations. Although the majority of tunnel fires are relatively small events, they nevertheless have the potential to evolve into more serious events depending on various factors: tunnel design; location of the tunnel; geometry of the road; monitoring; technical standard of the vehicles; traffic regulation; and speed limits or driving culture [3]. Fully developed fires in the cargo of heavy goods vehicles and pool fires of burnable liquids can develop very high heat release rates [4]. Temperatures in the ceiling and wall surfaces can reach from $400^{\circ} \mathrm{C}$ (private car) to $1400^{\circ} \mathrm{C}$ (heavy goods vehicle) in the early stages of a fire, and persist for hours [5] with dramatic consequences for tunnel structure.

Different phases can be defined in the development of a fire inside a tunnel that are important for the integrity of the structure [6]: a) the structural stability fully conditions the time available for evacuation; b) the safety conditions during post-fire inspection; and c) the scope of repair and the time during which traffic will be disrupted after a fire. The effect of high temperature on tunnel lining has been studied using full-scale tests [5]. The heat generated during a major fire may cause a dramatic drop in concrete strength and spalling that exposes reinforcement to high temperatures and accelerating structural degradation. Even fire-resistant advances for lining protection can never completely prevent concrete weakening and spalling due to high temperatures, so heat will transfer through the lining to the rock mass. Obviously, rock mass will be quickly exposed to high temperature in a tunnel fire if there is no reinforced concrete or only a thin layer of shotcrete.

Some studies are specifically focused on the evaluation of the performance of the rock mass of a tunnel affected by fire. Smith and Pells [7] used real fire to register substantial explosive spalling events at relatively low temperatures (little more than the boiling point of water) on sandstone tunnels in Australia. Moreover, these authors observed a decrease in uniaxial compression strength and elastic modulus in sandstone samples when using an electrical furnace. Conclusions on rock spalling were later confirmed in a real accident [8], and the generation of steam pressure was recognised as the main mechanism causing spalling. Studies on tunnels in igneous rocks in Sweden [9] enabled the identification of ranges of temperatures causing key variations in the mineralogical, physical, and mechanical properties of rocks. These authors generated high temperature gradients to simulate standard time-temperature curves. The results showed a strong dependence of micro-crack formation on the mineralogy, as well as a direct influence on the reduction in compression strength.

The study of the variation in physical, mineralogical, and mechanical properties of rocks with temperature, not specifically focused on tunnel engineering, is an issue of current interest among the scientific community due to its application in various fields such as mining [10], cultural heritage [11,12], geothermal energy [13], or underground storage of radioactive waste [14]. Research points to heating as the cause for decay in rock integrity, and where magnitude and key temperatures strongly depend on the type of rock and their diverse physical and mineralogical properties. Some of the above mentioned works are focused on limestones, one of the most common types of sedimentary rocks. Lion et al. [15] described a decrease in strength due to microcracking at low temperatures $\left(\mathrm{T}<250^{\circ} \mathrm{C}\right.$ ) in a limestone from Anstrude (France). Yavuz et al. [16] observed that microcracking does not seem to occur below $150^{\circ} \mathrm{C}$ on limestones from Turkey; while marked decreases in bulk density, PYavuz et al. (2010) wave velocity, and effective porosity were registered at $400^{\circ} \mathrm{C}$. Andriani and Germinario [17] observed a clear reduction in uniaxial compression strength (UCS) from $500^{\circ} \mathrm{C}$ on calcareous and dolomitic rocks from Apulia in Italy. Temperatures above $600^{\circ} \mathrm{C}$ usually mark a dramatic decline in UCS [18,19]. Zhang et al. [20] studied limestones from Linyi (China) noting that from 200 to $500{ }^{\circ} \mathrm{C}$ the porosity and pore volume rapidly increased, and from 500 to $600{ }^{\circ} \mathrm{C}$ the maximum strength, elastic modulus, Poisson's ratio, and hardness decreased - while peak strain continuously increased. Crosby et al. [21] observed a lowering of peak strength at confining pressures up to $10 \mathrm{MPa}$ on triaxial tests caused by microcracking that did not affect the strength of the heated Salem limestone at greater pressures. Induced microcracking by thermal treatment lowered peak strength at confining 
pressures up to $10 \mathrm{MPa}$ on triaxial tests, and did not affect the strength of limestone at greater pressures. Zhang and LV [22] found a strong relationship between the mineral content and limestone properties under the effect of temperature for limestone from Shandong Province (China).

Valuable general knowledge about the thermal performance of limestone has been produced. Nevertheless, case-studies focused on the thermal performance of rock where future tunnels are to be drilled are still scarce. Therefore, we consider that certain features could be found in the thermal performance of limestone formations that fully condition fire emergency interventions, as it is known that certain temperature ranges and cooling methods usually compromise the stability of rock. Understanding the thermal performance of rock enables predicting mechanical parameters by using non-destructive tests on heated limestone and correlations whose determination is quick and easy. Previous research mainly focused on rocks at room temperature and estimated the UCS using simple regression analysis, multivariate regression analysis, or soft-computing tools such as neural networks and adaptive neuro-fuzzy inference systems. Predictors in most cases were physical properties such as mineral grain characteristics [23-27], density, porosity, and wave velocity [28-33]. Such correlations strongly depend on the type of rock, so some studies are focused on carbonate specimens [34-38]. Little research is available on strength prediction for thermally-treated rocks. Multivariate analysis enabled the prediction of thermal damage on Dholpur sandstone (India) from temperature and mechanical parameters (i.e. compressive strength, failure strain, and elastic modulus) [39]. Dholpur sandstone was also studied after thermal treatment using multivariate regression analysis to predict changes in strength from temperature and physical properties (such as density, porosity, thermal expansion coefficients, and ultrasonic waves). These predictions improved when using artificial neural network and adaptive neuro-fuzzy inference systems (coefficients of determination were close to 1) [40]. Such techniques and predictors were used to improve the prediction of thermal damage [41].

In this research, laboratory tests have been made on samples from two horizontal boreholes drilled during the design stage of the Tres Ponts Tunnel, which will be entirely excavated from Prada limestone in the Catalan south Pyrenean zone (Spain). Samples were thermally treated at temperatures of $105,200,300,400,500$ and $600^{\circ} \mathrm{C}$, then cooled using two methods: air-cooling (slow rate) and water-cooling (rapid rate) to simulate different modes of fire intervention. Variations in chemical composition and microstructure, physical (open porosity, volume, dry total weight, $\mathrm{P}$ - and S-wave velocities), and mechanical (uniaxial compressive strength, elastic modulus, and Poisson's ratio) properties were analysed. Various Prada formation features were observed such as key temperatures for rock weakening, and the influence of the cooling method. Statistical techniques (ANOVA and linear regression) were used to study the influence of the natural location of the samples (borehole and depth) on property variation and so explore the viability of comparing results between different samples and generalising the results throughout the tunnel. Finally, some correlations have been proposed to indirectly determine the variation in resistance and elasticity from the variation in physical properties (such as volume, open porosity, and P-wave velocity) with temperature. This research fills a gap on correlating parameters for thermally treated limestone. The results also provide a valid approach to predict the effects of a fire in the Tres Ponts Tunnel by helping in planning intervention protocols for emergency response teams, predicting times available for evacuation, evaluating safety conditions during post-fire inspections, as well estimating the extent of the damage and the time needed for repair.

\section{Materials and Methods}

\subsection{Sample preparation}

The Tres Ponts Tunnel is planned on the $\mathrm{C}-13$ road near Organyà in the Catalan south Pyrenean zone (Spain). The tunnel is oriented north-south, measures $1273 \mathrm{~m}$ in length, and will have a maximum depth of $285 \mathrm{~m}$. It will be entirely excavated from Prada limestone, a lower cretaceous limestone formation with a mudstone-wakestone texture and fossil fauna [42]. Rock samples were taken from two horizontal survey boreholes drilled during the design stage. Boreholes 1 and 2 were in the southern and northern mouths of the tunnel and reached prospection depths of $65.30 \mathrm{~m}$ and $91.45 \mathrm{~m}$, respectively. The planning and performance of the survey works was led by an independent engineering consultancy in charge of tunnel design. 
Therefore, the position and depth of the boreholes were decided according to tunnel design criteria.

Borehole cores with a diameter of $65 \mathrm{~mm}$ were cut with a slenderness of 2.5 to perform uniaxial compression strength tests according to International Society for Rock Mechanics (ISRM) standards. Samples were very homogeneous and only presented small changes in the grey tone and very thin veins of calcite. Furthermore, no changes were observed in the material composition throughout the length of the boreholes. Five cylindrical samples and five irregular fragments were used for the determination of the rock properties for each temperature and cooling method. This number of samples was defined by the limited availability of borehole rock cores, and the minimum number of specimens recommended by the ISRM standard for the uniaxial compression strength test [43]. Thus, a total of 55 cylindrical samples of $63 \mathrm{~mm}$ in diameter and a slenderness of 2.5 were randomly selected from both horizontal boreholes to perform ultrasound and uniaxial compression strength tests. In addition, 55 irregular fragments were selected to determine unit weight and open porosity variation with temperature, mercury intrusion porosimetry tests, and scanning electron microscopy observations. Figure 1 illustrates the number of laboratory tests performed for each temperature and the number of samples used.

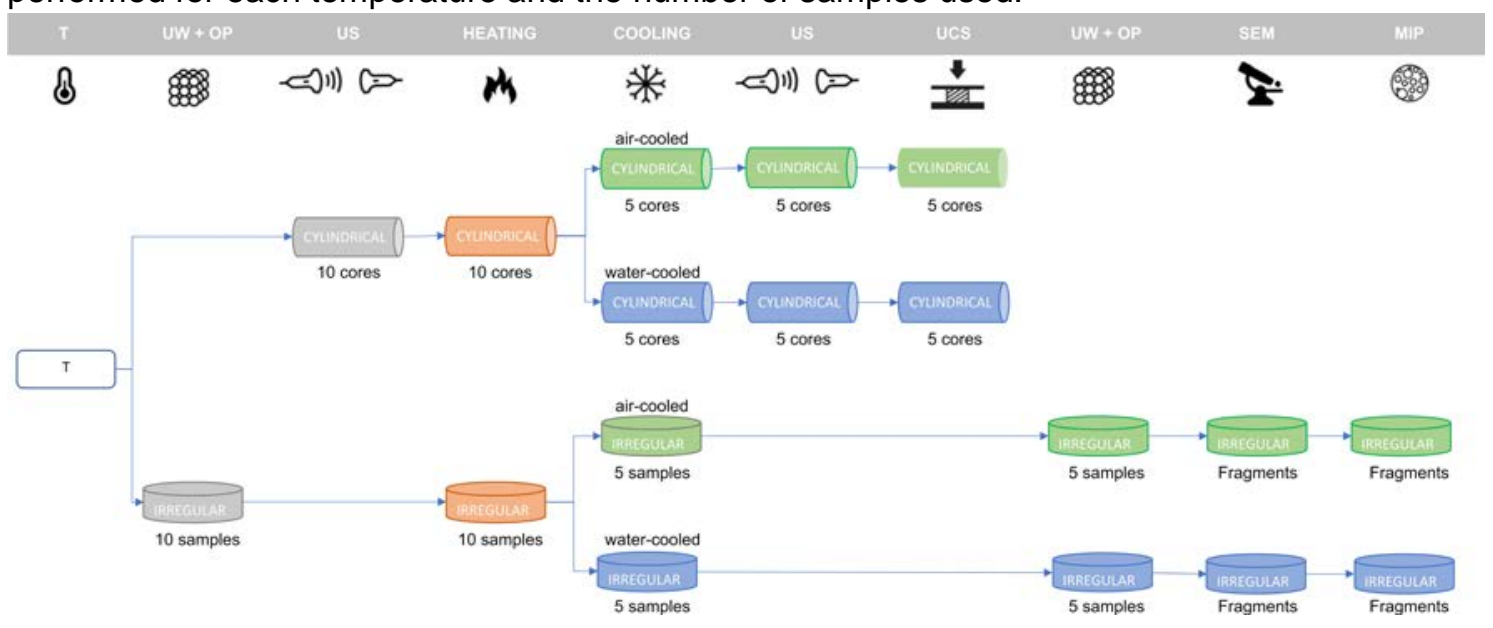

Figure 1. Laboratory tests and the number of cylindrical and irregular samples tested at each temperature $(\mathrm{T})$ to determine: unit weight (UW); open porosity (OP); ultrasound wave velocity (US); uniaxial compression strength (UCS); microstructure by scanning electron microscopy (SEM); and pore distribution by mercury intrusion porosity (MIP).

\subsection{Heating and cooling procedures}

Research reveals that water content can play a key role in the determination of UCS and the deformational features of the intact rock, even for small variations in the moisture content due to changes in the relative humidity of the air $[44,45]$. Natural moisture in rocks is also related to spalling events at temperatures lower than $200^{\circ} \mathrm{C}$ [7-9]. Even when water absorption in Prada limestone is extremely low $(0.45 \pm 0.20 \%)$, we decided to study its properties after moisture was completely removed by pre-heating the samples. Although such initial heating may induce microstructural effects in the rock, we are interested in the micro and macro-structural effects of high temperatures and its implications for Tres Ponts Tunnel fire-intervention protocols. Thus, a temperature of $105^{\circ} \mathrm{C}$ was initially applied to remove moisture from the rock samples for the determination of the intact rock properties and in line with other authors $[11,16,18]$. Subsequently, the samples were subjected to thermal treatment in a furnace at temperatures of $200,300,400$, 500 and $600^{\circ} \mathrm{C}$. Thermal treatment was limited to $600^{\circ} \mathrm{C}$ as the rock lost its integrity at higher temperatures due to mass cracking, and so preventing open porosity, ultrasonic, and UCS tests. A gradient of $5^{\circ} \mathrm{C} / \mathrm{min}$ was applied to reach the target temperatures and once reached, it was maintained for one hour. Samples heated at 400,500 , and $600{ }^{\circ} \mathrm{C}$ were cooled at a slow rate inside the furnace to $300^{\circ} \mathrm{C}$ to ensure a safe manipulation of the rock, and then the furnace was opened. To simulate different modes of fire intervention equipment, samples were cooled in one of two ways: air-cooled at a slow rate to room temperature; or by rapid cooling using water 
immersion according to the procedure described by Brotóns et al. [11]. A thermocouple registered the temperature inside the furnace every minute using a PicoLog 6 data logger.

\subsection{Laboratory tests}

Rock fragments were pulverised after being heated to 105,300 , and $500^{\circ} \mathrm{C}$. Total carbon and sulphur content was then determined using an Eltra CS IR spectrometer after heating in a furnace. The whole rock analysis was performed by fusion and X-ray fluorescence (XRF) using XRF Panalytical Axios Fast. Optical and scanning electron microscopy (SEM) in backscattered electron mode was used to study the petrographic features of Prada limestone. Sample surfaces were polished with alumina and diamond powder; the finest abrasive used was a $0.4 \mathrm{~mm}$ diamond powder. Uncovered polished surfaces were studied in a Hitachi S-3000 N variable pressure SEM working in a low vacuum, and salt tested surfaces were analysed in a high vacuum SEM in secondary electron mode. Mercury intrusion porosimetry (MIP) was used to obtain pore size distribution in samples thermally treated at 105,300 , and $600^{\circ} \mathrm{C}$. Tests were developed with a PoreMaster 60 GT (Quantachrome Instruments). The employed surface tensions and contact angles of mercury were $480 \mathrm{mN} / \mathrm{m}$ and $130^{\circ}$, respectively.

Open porosity and unit weight values before and after thermal treatment were determined using irregular samples. To do so, saturation and buoyancy techniques were applied according to the methods suggested by the ISRM [46]. Ultrasonic measurements were carried out over cylindrical samples before and after thermal treatment, according to the ISRM suggested method [47]. The transmission method consisted of two Olympus V1548 $0.1 \mathrm{MHz}$ piezoelectric sensors coupled to the sample at constant pressure. Compressive $(P)$ and shear $(S)$ waves were measured using polarised Olympus transducers videoscan V1548 $(0.1 \mathrm{MHz})$. Emitting-receiving equipment (Proceq Pundit lab + ) was used to acquire and digitalise the waveforms to be displayed, manipulated, and stored.

UCS tests were performed on cylindrical samples with a slenderness of 2.5 according to the ISRM suggested method [43]. Core faces were polished to ensure flatness and perpendicularity relative to the axis. A four-column press machine (Mecánica Científica SA model 28.5200) with a capacity of $2000 \mathrm{kN}$ was used, and a compression rate of $0.5 \mathrm{MPa} / \mathrm{s}$ was applied until the ultimate load. Strain gauges (Tokyo Measuring Instruments Lab PF-30-11) of $30 \mathrm{~mm}$ long $(120.3 \pm 0.5 \Omega$, $\mathrm{k}=2.13 \pm 1$ ) were used for longitudinal and lateral strains. Values were registered for each loading cycle using MecaSoft software v.1.3.8. Young's tangent modulus and the corresponding Poisson ratio were determined from values of $50 \%$ of the ultimate sample load according to the ISRM suggested method mentioned above.

\subsection{Statistical analysis}

A variance analysis (ANOVA) was performed to determine the potential influence of the sample position on the results. P-wave velocity normalised to the same samples at a reference temperature of $105^{\circ} \mathrm{C}$ was chosen to study the influence of the sample's position on results before thermal treatment, since it is a parameter closely linked with other properties such as porosity, elastic modulus, or the Poisson ratio. Normalised P-wave velocity and uniaxial compression strength were chosen to study the influence of sample position on results after heating. The variables described above were compared with other factors to evidence relative influence (such as the position of the samples in the boreholes, the borehole from which they were extracted, the temperature variation, and the cooling method). F-tests enabled the identification of the main factors in the variability of each studied property, and the verification of the null hypothesis (i.e., no difference between means for $F=1$ ). P-values tested the statistical significance of each factor (statistical significance for $\mathrm{F}<0.05$ ). Additionally, a simple regression analysis was performed as an alternative method to study the dependence between P-wave velocity for intact samples, the depth of extraction of the sample in the boreholes, and the borehole from which the samples were extracted.

Finally, several correlations have been proposed to predict the variation in peak strength and elastic modulus from the variation in physical properties (such as volume, open porosity, and Pwave velocity) as a useful, simple, and quick method to estimate the mechanical properties of the rocks after a tunnel fire. Mean values of peak strength, elastic modulus, and normalised physical 
variables for each temperature have been used, and the best-fitting linear, exponential, logarithmic, or potential curves (fitted using the least squares method) have been adopted. The coefficient of determination $\left(\mathrm{R}^{2}\right)$ and the residuals (the difference between predicted and observed values) have been used to evaluate the goodness-of-fit of the data to the curve.

\section{Results}

\subsection{Geochemical and microstructural characterisation}

Mineral elements in Prada limestone before and after heating were obtained using XRF analysis (Table 1). The analysis showed that $\mathrm{CaO}$ was the most abundant element at all temperatures, followed (by far) by $\mathrm{MgO}$. Clay minerals such as $\mathrm{SiO}_{2}, \mathrm{Al}_{2} \mathrm{O}_{3}$, and $\mathrm{Fe}_{2} \mathrm{O}_{3}$ appeared in proportions of less than $1 \%$. $\mathrm{SiO}_{2}$ was the dominant compound and this is related to the presence of quartz. Thermal treatment enabled the identification of an important proportional decrease in $\mathrm{MgO}$ with temperature, while $\mathrm{CaO}$ remained almost constant. Indicative mineral composition of Prada limestone in terms of the proportion of calcite, dolomite, and argillaceous material was deduced following the procedure described by Meng et al. [48] and based on the chemical affinity of compounds to mineral elements (obtained by XRF) and the ratio of molecular weight. Results show that the primary mineral component of the intact rock is calcite (Cc) with a proportion above $93 \%$ that increased with temperature (Table 2). The content of dolomite (Cd) was above $6 \%$ for the intact rock and this proportion decreased with temperature. Argillaceous material $(\mathrm{Ca})$ showed a proportion of around $1 \%$ for all temperatures.

Table 1. Mineral element content of Prada limestone at different temperatures.

\begin{tabular}{cccccc}
\hline $\begin{array}{c}\text { Temperature } \\
\left({ }^{\circ} \mathrm{C}\right)\end{array}$ & $\mathrm{CaO}(\%)$ & $\mathrm{MgO}(\%)$ & $\mathrm{Al}_{2} \mathrm{O}_{3}(\%)$ & $\mathrm{SiO}_{2}(\%)$ & $\mathrm{Fe}_{2} \mathrm{O}_{3}(\%)$ \\
\hline 100 & 54.30 & 1.34 & 0.11 & 0.65 & 0.19 \\
300 & 54.40 & 0.78 & 0.16 & 0.95 & 0.21 \\
500 & 54.15 & 0.47 & 0.12 & 0.83 & 0.11 \\
\hline
\end{tabular}

Table 2. Mineral composition of Prada limestone before and after heating.

\begin{tabular}{cccc}
\hline $\begin{array}{c}\text { Temperature } \\
\left({ }^{\circ} \mathbf{C}\right)\end{array}$ & Cd (\%) & Cc (\%) & Ca (\%) \\
\hline 100 & 6.11 & 92.95 & 0.95 \\
300 & 3.57 & 95.13 & 1.31 \\
500 & 2.16 & 96.76 & 1.07 \\
\hline
\end{tabular}

SEM enabled the identification of micro-defects of increasing magnitude in Prada limestone when heated. Initial trans-granular fissures and porosity could be appreciated when heating to $400^{\circ} \mathrm{C}$, with no significant differences between air- (Figure 2a) and water-cooled samples (Figure $2 b$ ). Pore-size increase and fissure growth could be clearly appreciated at $500^{\circ} \mathrm{C}$. When that temperature was reached, isolated fissures were observed in air-cooled samples (Figure 2c), and fissures were larger and more connected in water-cooled samples (Figure 2d). Well-formed fissures could be observed at $600^{\circ} \mathrm{C}$ for both air (Figure 2e) and water-cooled samples (Figure 2f). MIP analysis reflected dual porosity features on samples heated at $105^{\circ} \mathrm{C}$ (Figure 3). A small size pore family is recognised (in the range of 0.006-0.02 $\mu \mathrm{m}$ ) that represents the interparticle porosity defined by grain minerals, cements, and fine-grains. A second pore family representing micro-fissures, which are more abundant and appear in larger sizes $(4-10 \mu \mathrm{m})$ can also be recognised. Samples heated at $300^{\circ} \mathrm{C}$ and then air-cooled show an increase in the number of pores and large micro-fissures $(>200 \mu \mathrm{m})$ that MIP cannot measure completely. Results show differences when samples are heated to $300^{\circ} \mathrm{C}$ and cooled with water, where pores smaller than $10 \mu \mathrm{m}$ almost disappear (attributable to a disaggregation of the samples induced by the effect of water immersion). It is remarkable that retained mercury was maximum in samples heated at $300^{\circ}$ C ( $\mathrm{Hg}$ retained $89 \%)$ probably due to a growth in pore size and a lack of connections that leads to an accumulation of mercury in the sample. Finally, samples heated to $600^{\circ} \mathrm{C}$ show new pores in a wide range of sizes that seem to be more connected than in those samples heated to lower temperatures due to a smaller volume of retained mercury $(\mathrm{Hg}$ retained $74 \%)$. 

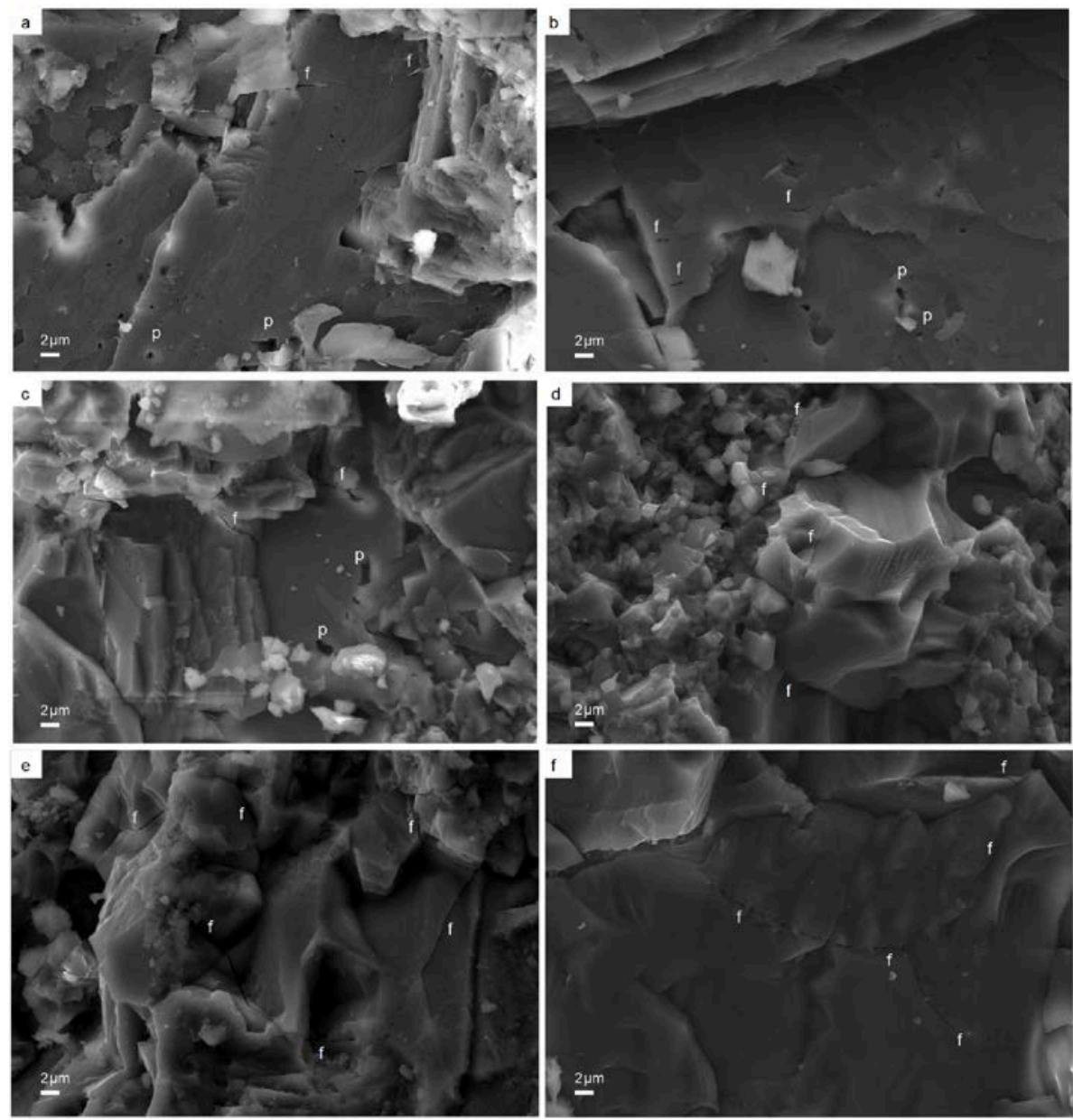

Figure 2. SEM images showing pores (p) and fissures ( $f$ ) for different temperatures and cooling methods. An increase of $2000 x$ was used for all figures.

a)

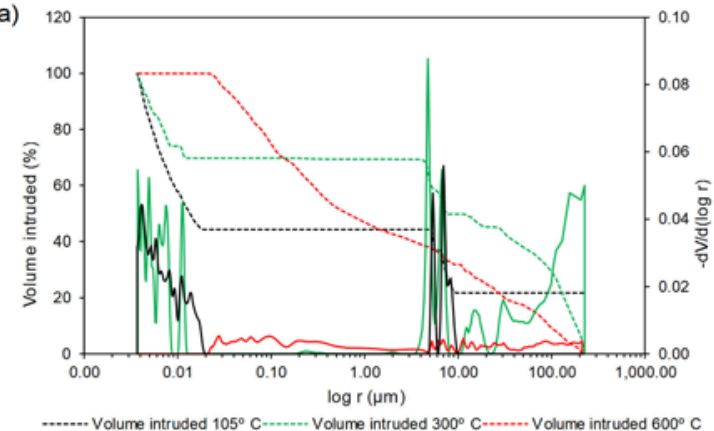

- dV $/ d(\log r) 600^{\circ}$

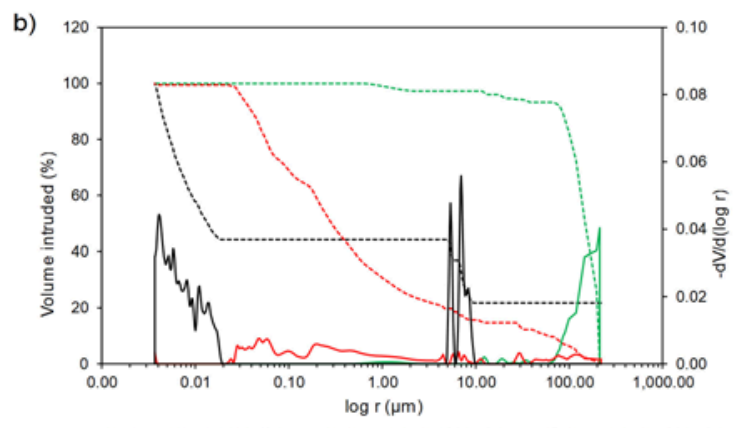

-...-.-. Volume intruded $105^{\circ} \mathrm{C}-\cdots-\cdots-$-.- Volume intruded $300^{\circ} \mathrm{C}-\cdots-\cdots-$-.- Volume intruded $600^{\circ} \mathrm{C}$

Figure 3. Cumulative mercury intrusion and pore size distribution for samples heated at different temperatures and cooled by (a) air; and (b) water immersion.

\subsection{Variation of physical properties}

The average initial values for physical and mechanical properties were initially determined for the intact rock (defined at a reference temperature of $105^{\circ} \mathrm{C}$ ) and are summarised in Table 3. Variations in physical properties (open porosity, volume, dry total weight, P- and S-wave velocities) with temperature were studied using normalised values (i.e., results after heating were divided by those of the same samples obtained at the reference temperature of $105^{\circ} \mathrm{C}$ ). 
The variation in open porosity was small at low and intermediate temperatures (Figure 4). A marginal reduction in open porosity (slightly greater for water-cooled samples) was reported at $200^{\circ} \mathrm{C}$. A gentle increase with temperature was then observed up to $400^{\circ} \mathrm{C}$ (a slightly greater increase is observed at $300^{\circ} \mathrm{C}$ for water-cooled samples). For all cooling methods, appreciable changes appeared at $500^{\circ} \mathrm{C}$, where open porosity tripled the initial porosity. Moreover, an appreciable rise in standard deviation was observed as the temperature increased. Additionally, differences are noticeable at $600^{\circ} \mathrm{C}$ according to the cooling method as samples cooled by water immersion and air exhibit dramatic increases in mean total porosity of up to 5.68 and 3.82 , respectively. Therefore, open porosity showed the greatest variation with temperature among all the studied physical parameters. The variation of volume with temperature exhibited a similar trend to open porosity (Figure 5). Variation in volume was of two orders of magnitude smaller than that observed for open porosity. It is worth noting that dry total weight showed almost negligible variations with the temperature, suggesting that volume change is mainly responsible for the observed variation in dry density. The ultrasound wave velocity decreased with temperature (Figure 6). Differences between cooling methods appeared at $400^{\circ} \mathrm{C}$, since water-cooled samples exhibited a significant reduction. At $500^{\circ} \mathrm{C}$ a considerable decrease in ultrasound velocities for both air and water-cooled samples was observed. Finally, the lowest values of Pand S-wave velocities were reached at $600^{\circ} \mathrm{C}$, and this was mostly noticeable for water-cooled samples.

Table 3. Reference values for samples forming Prada limestone, heated at $105^{\circ} \mathrm{C}$.

\begin{tabular}{cc}
\hline Parameter & Value \\
\hline Dry unit weight, $\rho_{\mathrm{d}}\left(\mathrm{kN} / \mathrm{m}^{3}\right)$ & $26.84 \pm 0.25$ \\
Water absorption $(\%)$ & $0.45 \pm 0.20$ \\
Unit weight of solids, $\mathrm{Ys}_{\mathrm{s}}\left(\mathrm{kN} / \mathrm{m}^{3}\right)$ & $27.21 \pm 0.01$ \\
Thermal conductivity, $\mathrm{k}(\mathrm{W} / \mathrm{mk})$ & $3.50 \pm 0.01$ \\
Open porosity, $\mathrm{n}_{\mathrm{e}}(\%)$ & $1.21 \pm 0.54$ \\
Total porosity, $\mathrm{n}(\%)$ & $1.46 \pm 0.91$ \\
P-wave velocity, $\mathrm{V}_{\mathrm{p}}(\mathrm{km} / \mathrm{s})$ & $5.35 \pm 0.06$ \\
S-wave velocity, $\mathrm{V}_{\mathrm{s}}(\mathrm{km} / \mathrm{s})$ & $2.65 \pm 0.02$ \\
Uniaxial compressive strength, $\sigma_{\mathrm{ci}}(\mathrm{MPa})$ & $164.63 \pm 23.77$ \\
Elastic modulus, $\mathrm{E}(\mathrm{GPa})$ (from mechanical tests) & $77.69 \pm 6.54$ \\
Poisson's ratio, $v$ (from mechanical tests) & $0.31 \pm 0.05$ \\
\hline
\end{tabular}

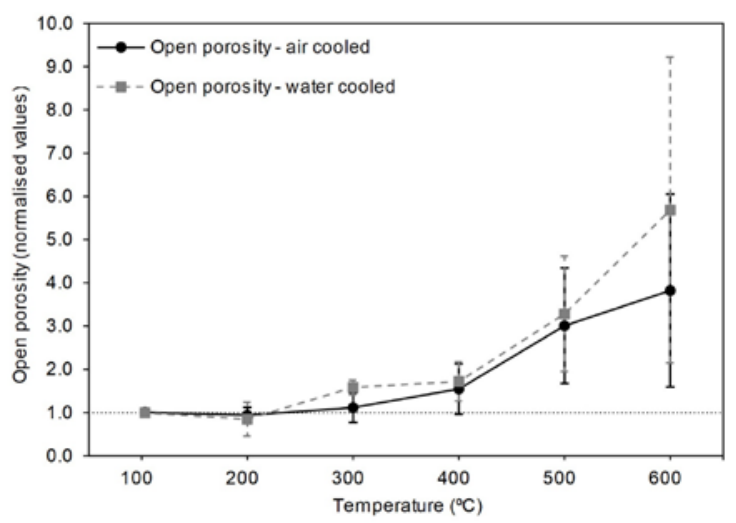

Figure 4. Open porosity (normalised values) for air and water-cooled samples. 


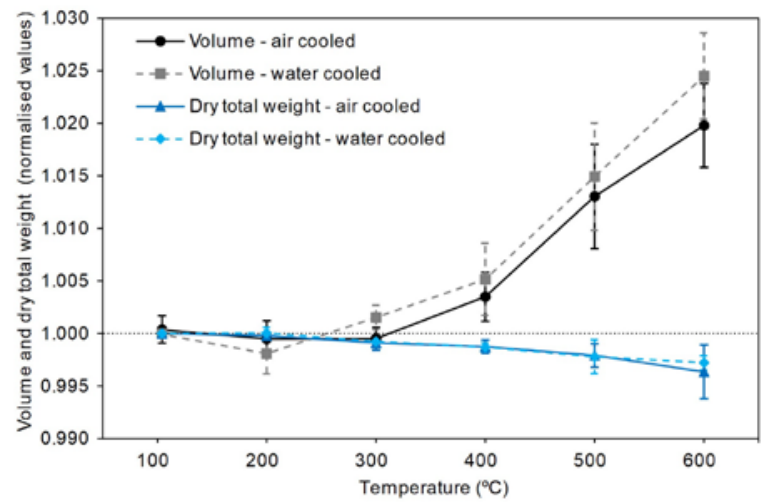

Figure 5. Volume and dry total weight (normalised values) for air and water-cooled samples.
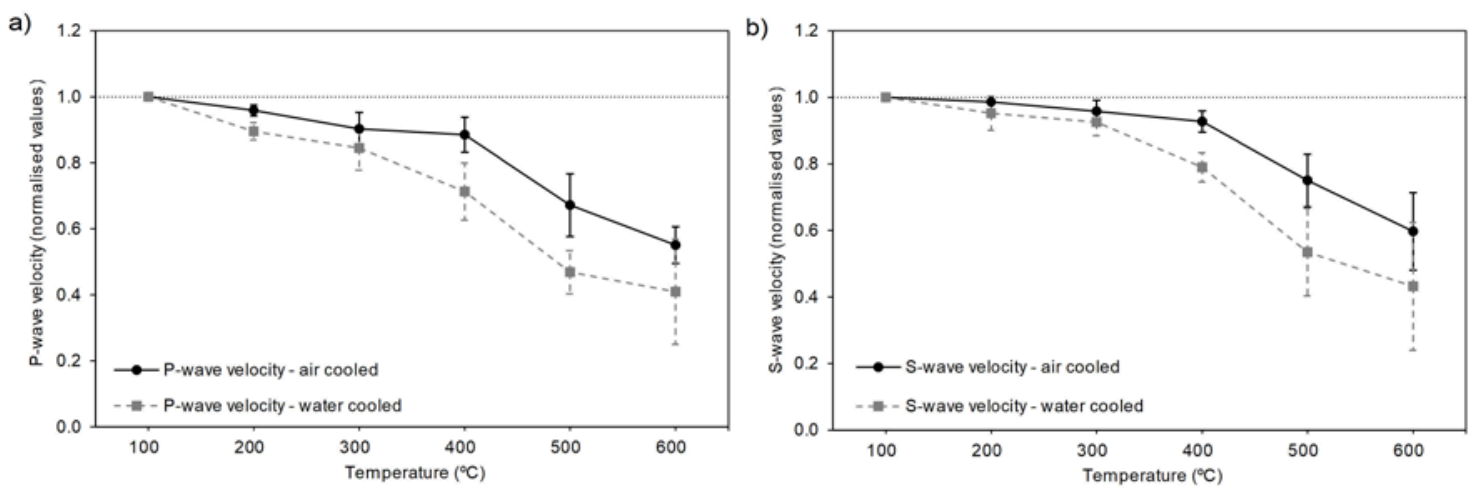

Figure 6. P- (a) and S-wave (b) velocities (normalised values) for air and water-cooled samples.

\subsection{Variation of mechanical properties}

Given the destructive nature of the UCS test, it was not possible to obtain values before and after heating for a single sample. Therefore, changes in UCS, elastic modulus, and Poisson's ratio with temperature were studied using absolute values instead of normalised values. UCS results exhibited significant values of standard deviation at certain temperatures which hampered the identification of local changes (Figure 7). However, the general trend showed a steady decrease in UCS (even at a low temperature of $200^{\circ} \mathrm{C}$ ) and final value at $600^{\circ} \mathrm{C}$ was of above 20 $\%$ that for the intact rock. The mean values and the small standard deviations at 400 and $500^{\circ} \mathrm{C}$ in the air-cooled samples are consistent with a slight increase in the values of UCS, or at least a stabilisation in the variable. Values showed a more substantial reduction of UCS at $500^{\circ} \mathrm{C}$ in those samples cooled by water immersion. Finally, mean values at $600^{\circ} \mathrm{C}$ reached minimum values for both cooling methods, and the considerable standard deviations prevent a full confirmation that samples cooled with water achieve a lower resistance than those cooled in air for the studied range of temperatures. During the mechanical tests, the axial and lateral deformations and the axial load were recorded. Figure 8 shows the stress-strain diagram for representative air- (a) and water-cooled (b) samples. The features of the stress-axial strain curve for air-cooled samples did not present significant changes up to $300^{\circ} \mathrm{C}$, and then an abrupt increase in ductility is observed for both 400 and $500^{\circ} \mathrm{C}$. In the case of water-cooled samples, the increase in ductility was more progressive except for an abrupt increase at $400^{\circ} \mathrm{C}$. We observe a marked elastic axial deformation after the compression phase and a lack of brittle deformation for both cooling methods. Axial stress-lateral strain curves show a progressive increase in the transverse ductility of the samples. 


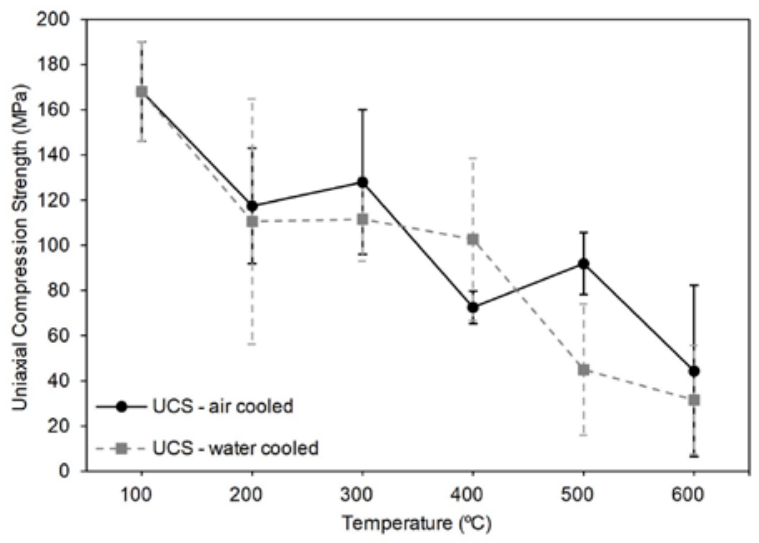

Figure 7. UCS values for air and water-cooled samples.
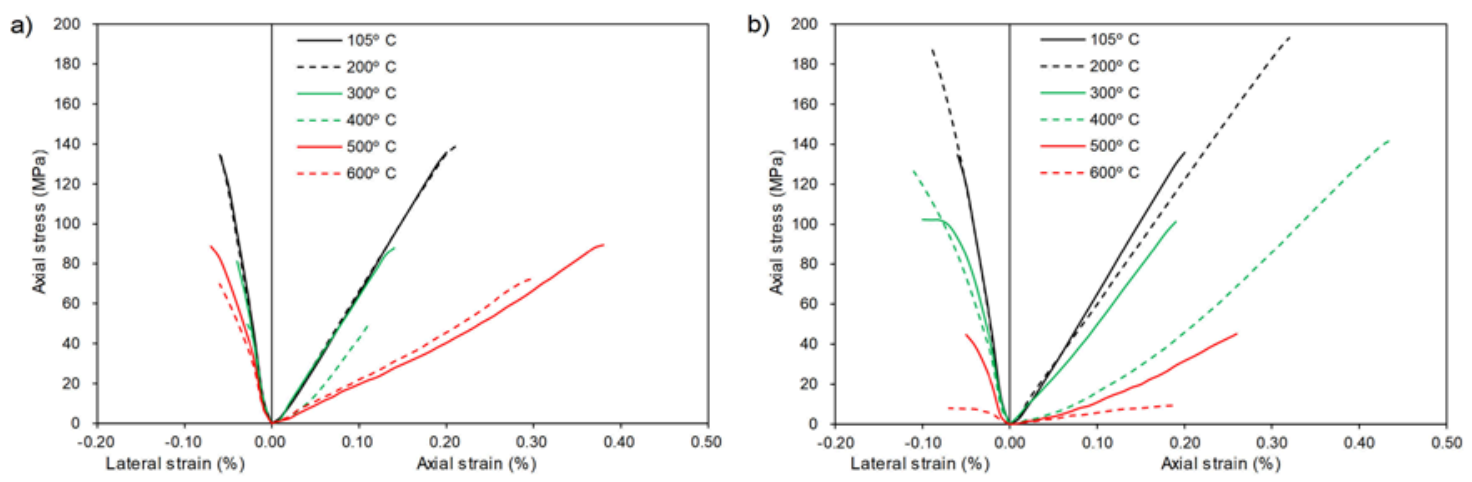

Figure 8. Stress-strain curves for samples heated at different temperatures and then air- (a) or water-cooled (b).

Elastic modulus (E) also showed a sustained decrease with temperatures up to about a quarter of the values obtained for the reference samples heated at $105^{\circ} \mathrm{C}$ (Figure 9a). The influence of cooling methods was clearly noticeable at $400^{\circ} \mathrm{C}$, where water-cooled values registered an abrupt decrease. Final values at $600^{\circ} \mathrm{C}$ were above $25 \%$ of the intact rock at $105^{\circ}$ $\mathrm{C}$ for air-cooled samples, and $11 \%$ in water-cooled samples. Although a slight increase in the mean value could be observed at $600^{\circ} \mathrm{C}$ for air-cooled samples, standard deviations reported at 500 and $600^{\circ} \mathrm{C}$ are not negligible. Therefore, we conclude that the observed trend is consistent with a stabilisation in the variable. Poisson's ratio also showed a clear reduction with temperature (Figure 9b). Final values at $600^{\circ} \mathrm{C}$ were near one-third of the values obtained for the intact rock at $105^{\circ} \mathrm{C}$ for both cooling methods. Finally, normalised values for dynamic elastic modulus (Figure 10) were computed following the ISRM suggested method [47] using ultrasonic wave velocity and density variation. The trends were similar to those obtained for P- and S-wave velocities. The differences between air- and water-cooled samples mainly appeared at $400^{\circ} \mathrm{C}$, as observed for the static elastic modulus. 

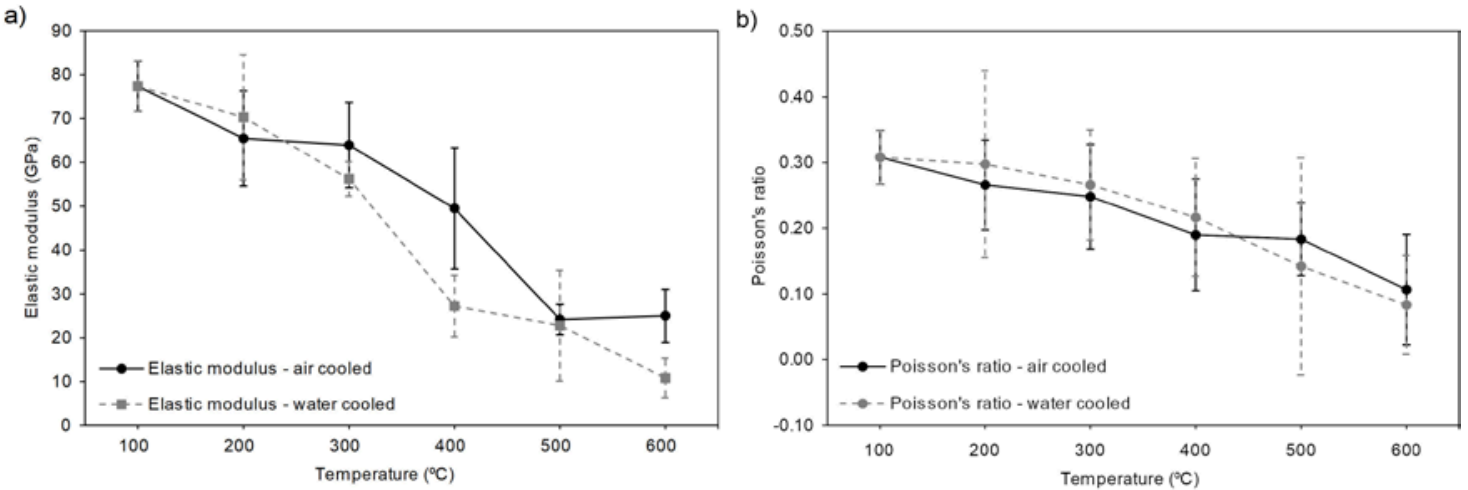

Figure 9. Elastic modulus (a) and Poisson's ratio (b) values for air and water-cooled samples.

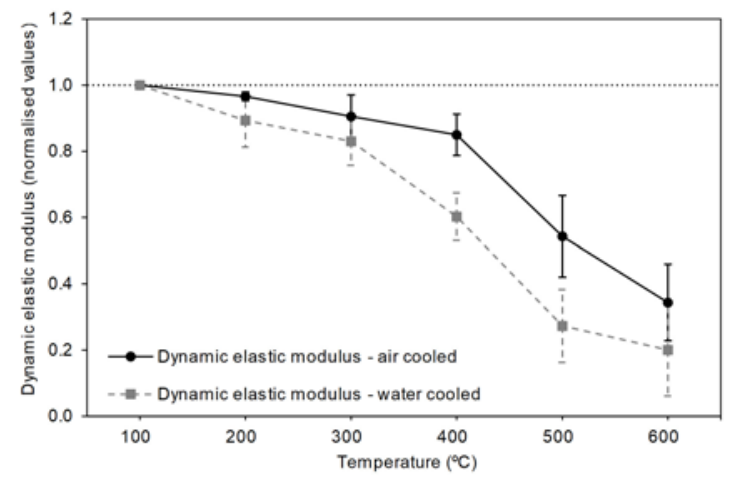

Figure 10. Dynamic elastic modulus (normalised values) for air and water-cooled samples.

\subsection{Influence of sample position on the variability of physical and mechanical properties}

The results from the performed ANOVA analysis are summarised in Table 4. They enable discarding statistical significance for the depth of samples and number of boreholes on the variation of P-wave velocity for intact samples, and of P-wave velocity and UCS for heated samples (since F-test values were around 1 and P-values were greater than 0.05). Moreover, ANOVA analysis enabled the identification of temperature and cooling method as factors with statistical significance. Depth in the horizontal borehole cannot explain the variability of P-wave velocity for intact samples for both boreholes, since the coefficient of determination of simple regression analysis (Figure 11) was extremely low. These results agreed with the ANOVA analysis and enabled discarding a significant influence of sample location on experimental results obtained in this study. As a conclusion, the laboratory results of the different samples can be compared regardless of the borehole from which they were obtained and their location within the borehole. This enables generalising laboratory results throughout the tunnel and opens the door for using correlations to determine variation in mechanical parameters from other physical variables.

Table 4. Results from ANOVA analysis.

\begin{tabular}{|c|c|c|c|c|}
\hline Variable & Factor & F-test & P-value & Significance \\
\hline \multicolumn{5}{|c|}{$\begin{array}{l}\text { P-wave velocity for intact } \\
\text { samples }(\mathrm{m} / \mathrm{s})\end{array}$} \\
\hline & Depth of samples (m) & 0.87 & 0.5365 & NO \\
\hline & Number of borehole (1 or 2 ) & 1.06 & 0.3070 & NO \\
\hline \multicolumn{5}{|c|}{$\begin{array}{l}\text { Normalised P-wave velocity } \\
\text { for heated samples }\end{array}$} \\
\hline & Depth of samples (m) & 0.90 & 0.5109 & NO \\
\hline & Temperature $\left({ }^{\circ} \mathrm{C}\right)$ & 54.63 & 0.0000 & YES \\
\hline & Cooling method (air or water) & 13.32 & 0.0000 & YES \\
\hline \multicolumn{5}{|c|}{$\begin{array}{l}\text { Normalised UCS for heated } \\
\text { samples }\end{array}$} \\
\hline & Depth of samples (m) & 2.10 & 0.0625 & NO \\
\hline & Temperature $\left({ }^{\circ} \mathrm{C}\right)$ & 12.32 & 0.0000 & YES \\
\hline & Cooling method (air or water) & 3.43 & 0.0406 & YES \\
\hline
\end{tabular}




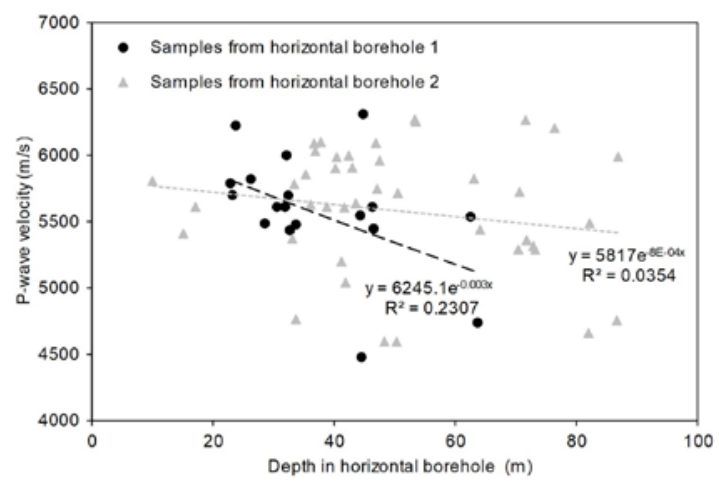

Figure 11. Simple regression analysis of P-wave velocity and sample position.

\subsection{Correlations between physical and mechanical properties}

As described above, some correlations have been proposed in this work to predict the variation of UCS and elastic modulus (E) from the variation in physical properties (volume, open porosity, and P-wave velocity) for both air and water-cooled samples. With this aim, simple regression curves and their respective coefficient of determination (R2) were calculated (Table 5). The best coefficients of determination were found when using exponential and potential curves. To discuss predictions of mechanical properties from physical parameters in detail, we have calculated the difference between the estimated and the observed values (i.e. the residuals) of UCS (Table 6) and E (Table 7). Potential functions were used in all cases, except to predict E from P-wave velocity, where exponential functions exhibited the best coefficients of determination.

The proposed functions for the prediction of UCS from normalised volume are represented in Figure 12a. Calculated values for air-cooled samples were greater than observed for intermediate temperatures of 200,400 and $600^{\circ} \mathrm{C}$, and smaller than observed at $500^{\circ} \mathrm{C}$. The average residual for all temperatures was $20 \mathrm{MPa}$, and $21 \mathrm{MPa}$ for the highest temperatures (400 to $600^{\circ} \mathrm{C}$ ). The fitting was better for water-cooled samples, especially for intermediate and higher temperatures $\left(300\right.$ to $600^{\circ} \mathrm{C}$ ). The average residual for all temperatures was $16 \mathrm{MPa}$, and $6 \mathrm{MPa}$ for the highest temperatures. Predicted values using normalised open porosity (Figure 12b) were greater for air-cooled samples than those observed for temperatures of 200,400 and $600^{\circ}$, and smaller at $500^{\circ} \mathrm{C}$. The average residual for all temperatures and the highest temperatures was $21 \mathrm{MPa}$. The obtained function showed better predictions for water-cooled samples, since the average residual for all temperatures was $20 \mathrm{MPa}$, and $7 \mathrm{MPa}$ for the highest temperatures. The correlation between UCS and normalised P-wave velocity was represented (Figure 12c). The average residuals for air-cooled samples were $22 \mathrm{MPa}$ for all data, and $25 \mathrm{MPa}$ for the highest temperatures. The fitted function was close to linear for water-cooled samples, and residuals were minimum for almost every temperature, since the average residual was $9 \mathrm{MPa}$ for all the dataset and $7 \mathrm{MPa}$ for the highest temperatures. Correlation functions exhibited good predictions for $\mathrm{E}$ for all physical parameters and cooling methods, and the residuals were in all cases lower than those obtained for UCS predictions. Predicted values for normalised volume are represented in Figure 13a, and for air-cooled samples were greater than those observed for intermediate temperatures of 400 and $500^{\circ} \mathrm{C}$, and smaller than those observed at $600^{\circ} \mathrm{C}$. The average residual for all temperatures and the highest temperatures was $5 \mathrm{GPa}$. The fitting was better for water-cooled samples for temperatures of 300,500 , and $600^{\circ} \mathrm{C}$, although predicted values for $400^{\circ} \mathrm{C}$ were clearly greater than observed. The average residual for all the dataset and for the highest temperatures was $6 \mathrm{GPa}$. Predicted values using normalised open porosity (Figure 13b) were greater for air-cooled samples than for those observed at $500^{\circ} \mathrm{C}$, and smaller at $600^{\circ} \mathrm{C}$. The average residual for all temperatures was $4 \mathrm{GPa}$, and $3 \mathrm{GPa}$ for the highest temperatures. Predicted values for water-cooled samples were greater than observed at $400^{\circ} \mathrm{C}$ and slightly lower at $500^{\circ} \mathrm{C}$. The average residual for all temperatures was $8 \mathrm{GPa}$, and $5 \mathrm{MPa}$ for the highest temperatures. Finally, the correlation between $\mathrm{E}$ and normalised P-wave velocity (Figure 13c) exhibited greater predicted values than those observed at 400 and $500^{\circ} \mathrm{C}$, and smaller at $600^{\circ}$ C. Average residuals for air-cooled samples were $4 \mathrm{GPa}$ for all data, and $5 \mathrm{GPa}$ for the highest temperatures. For water-cooled samples, the predicted values were smaller than those observed 
at 200 and $500^{\circ} \mathrm{C}$, and greater than those observed at 400 and $600^{\circ} \mathrm{C}$. The average residual was $5 \mathrm{MPa}$ for all the dataset and for the highest temperatures.

Table 5. Coefficients of determination $\left(R^{2}\right)$ for simple regression curves studied to predict UCS and elastic modulus $(\mathrm{E})$ from normalised $(\mathrm{N})$ physical parameters (volume, open porosity, and $\mathrm{P}$ wave velocity).

\begin{tabular}{cccccccccc}
\hline & & \multicolumn{4}{c}{$\mathbf{R}^{2}$ for UCS predictions } & \multicolumn{4}{c}{$\mathbf{R}^{\mathbf{2}}$ for E predictions } \\
Parameter (N) & Cooling & Linear & Exponential & Logarithmic & Potential & Linear & Exponential & Logarithmic & Potential \\
\hline \multirow{2}{*}{ Volume } & air & 0.61 & 0.69 & 0.61 & 0.69 & 0.86 & 0.90 & 0.86 & 0.90 \\
& water & 0.78 & 0.91 & 0.78 & 0.91 & 0.78 & 0.91 & 0.78 & 0.91 \\
\multirow{3}{*}{ Open porosity } & air & 0.60 & 0.67 & 0.64 & 0.68 & 0.88 & 0.92 & 0.93 & 0.96 \\
& water & 0.75 & 0.89 & 0.79 & 0.88 & 0.71 & 0.87 & 0.84 & 0.91 \\
P-wave velocity & air & 0.61 & 0.64 & 0.60 & 0.65 & 0.90 & 0.94 & 0.87 & 0.92 \\
& water & 0.93 & 0.95 & 0.91 & 0.97 & 0.91 & 0.92 & 0.86 & 0.91 \\
\hline
\end{tabular}

Table 6. UCS values from laboratory tests and predicted from normalised values $(\mathrm{N})$ of physical parameters for each temperature, based on potential functions. Residuals have been also represented.

\begin{tabular}{|c|c|c|c|c|c|c|c|c|c|c|}
\hline \multirow[b]{2}{*}{$\begin{array}{c}\text { Temperature } \\
\left({ }^{\circ} \mathrm{C}\right)\end{array}$} & \multirow[b]{2}{*}{ Cooling } & \multicolumn{3}{|c|}{ Volume (N) } & \multicolumn{3}{|c|}{ Open porosity (N) } & \multicolumn{3}{|c|}{ P-wave velocity (N) } \\
\hline & & $\begin{array}{c}\text { Predicted } \\
\text { UCS } \\
\text { (MPa) }\end{array}$ & $\begin{array}{c}\text { Measured } \\
\text { UCS } \\
\text { (MPa) }\end{array}$ & $\begin{array}{l}\text { Residual } \\
\text { (MPa) }\end{array}$ & $\begin{array}{c}\text { Predicted } \\
\text { UCS } \\
\text { (MPa) }\end{array}$ & $\begin{array}{c}\text { Measured } \\
\text { UCS } \\
\text { (MPa) }\end{array}$ & $\begin{array}{l}\text { Residual } \\
\text { (MPa) }\end{array}$ & $\begin{array}{c}\text { Predicted } \\
\text { UCS } \\
\text { (MPa) }\end{array}$ & $\begin{array}{c}\text { Measured } \\
\text { UCS } \\
\text { (MPa) }\end{array}$ & $\begin{array}{l}\text { Residual } \\
\text { (MPa) }\end{array}$ \\
\hline \multirow[t]{2}{*}{105} & air & 124.80 & 168.09 & -43.29 & 130.71 & 168.09 & -37.38 & 133.89 & 168.09 & -34.20 \\
\hline & water & 126.64 & 168.09 & -41.45 & 137.60 & 168.09 & -30.49 & 156.33 & 168.09 & -11.76 \\
\hline \multirow[t]{2}{*}{200} & air & 127.78 & 117.46 & 10.32 & 136.09 & 117.46 & 18.63 & 125.49 & 117.46 & 8.03 \\
\hline & water & 141.86 & 110.57 & 31.28 & 157.84 & 110.57 & 47.27 & 129.51 & 110.57 & 18.93 \\
\hline \multirow[t]{2}{*}{300} & air & 127.64 & 128.01 & -0.37 & 121.83 & 128.01 & -6.17 & 114.33 & 128.01 & -13.67 \\
\hline & water & 115.54 & 111.57 & 3.97 & 94.03 & 111.57 & -17.54 & 117.14 & 111.57 & 5.58 \\
\hline \multirow[t]{2}{*}{400} & air & 106.20 & 72.49 & 33.71 & 98.62 & 72.49 & 26.12 & 110.94 & 72.49 & 38.45 \\
\hline & water & 93.17 & 102.68 & -9.51 & 87.93 & 102.68 & -14.75 & 87.70 & 102.68 & -14.98 \\
\hline \multirow[t]{2}{*}{500} & air & 68.57 & 91.92 & -23.35 & 63.98 & 91.92 & -27.95 & 66.29 & 92.53 & -26.24 \\
\hline & water & 52.31 & 45.02 & 7.30 & 51.51 & 45.02 & 6.49 & 42.80 & 45.02 & -2.21 \\
\hline \multirow[t]{2}{*}{600} & air & 29.92 & 31.58 & -1.66 & 32.70 & 31.58 & 1.12 & 34.00 & 31.58 & 2.42 \\
\hline & water & 50.46 & 44.40 & 6.06 & 54.75 & 44.40 & 10.35 & 53.28 & 44.40 & 8.88 \\
\hline
\end{tabular}

Table 7. Elastic modulus (E) values from laboratory tests and predicted from normalised values $(\mathrm{N})$ of physical parameters for each temperature, based on potential functions except for P-wave velocity, where exponential functions enabled the best predictions. Residuals have been also represented.

\begin{tabular}{ccccccccccc}
\hline \multirow{2}{*}{$\begin{array}{c}\text { Temperature } \\
\left({ }^{\circ} \mathbf{C}\right)\end{array}$} & Cooling & $\begin{array}{c}\text { Predicted } \\
\text { E (MPa) }\end{array}$ & $\begin{array}{c}\text { Measured } \\
\text { E (MPa) }\end{array}$ & $\begin{array}{c}\text { Residual } \\
\text { E (MPa) }\end{array}$ & $\begin{array}{c}\text { Predicted } \\
\text { E (MPa) }\end{array}$ & $\begin{array}{c}\text { Measured } \\
\text { E (MPa) }\end{array}$ & $\begin{array}{c}\text { Residual } \\
\text { E (MPa) }\end{array}$ & $\begin{array}{c}\text { Predicted } \\
\text { E (MPa) }\end{array}$ & $\begin{array}{c}\text { Measured } \\
\text { E (MPa) }\end{array}$ & $\begin{array}{c}\text { Residual } \\
\text { E (MPa) }\end{array}$ \\
\hline \multirow{2}{*}{105} & air & 64.41 & 77.37 & -12.96 & 67.42 & 77.37 & -9.94 & 73.13 & 77.37 & -4.23 \\
& water & 60.45 & 77.37 & -16.92 & 67.49 & 77.37 & -9.88 & 82.28 & 77.37 & 4.91 \\
\multirow{2}{*}{200} & air & 66.32 & 65.48 & 0.84 & 71.01 & 65.48 & 5.53 & 65.54 & 65.48 & 0.06 \\
& water & 69.37 & 70.29 & -0.92 & 79.91 & 70.29 & 9.62 & 60.49 & 70.29 & -9.79 \\
\multirow{2}{*}{300} & air & 66.22 & 63.96 & 2.26 & 61.59 & 63.96 & -2.37 & 56.42 & 63.96 & -7.54 \\
& water & 54.08 & 56.22 & -2.15 & 42.24 & 56.22 & -13.99 & 54.73 & 56.22 & -1.50 \\
\multirow{2}{*}{400} & air & 52.79 & 49.52 & 3.27 & 46.92 & 49.52 & -2.60 & 57.66 & 49.52 & 8.14 \\
& water & 41.65 & 27.23 & 14.42 & 38.89 & 27.23 & 11.66 & 34.24 & 27.23 & 7.01 \\
\multirow{2}{*}{500} & air & 30.78 & 24.15 & 6.63 & 26.89 & 24.15 & 2.74 & 28.20 & 24.15 & 4.05 \\
& water & 20.68 & 22.76 & -2.08 & 20.13 & 22.76 & -2.62 & 16.22 & 22.76 & -6.53 \\
\multirow{2}{*}{600} & air & 21.08 & 25.00 & -3.92 & 22.01 & 25.00 & -3.00 & 22.04 & 25.00 & -2.97 \\
& water & 10.50 & 10.82 & -0.32 & 11.51 & 10.82 & 0.69 & 13.54 & 10.82 & 2.73 \\
\hline
\end{tabular}



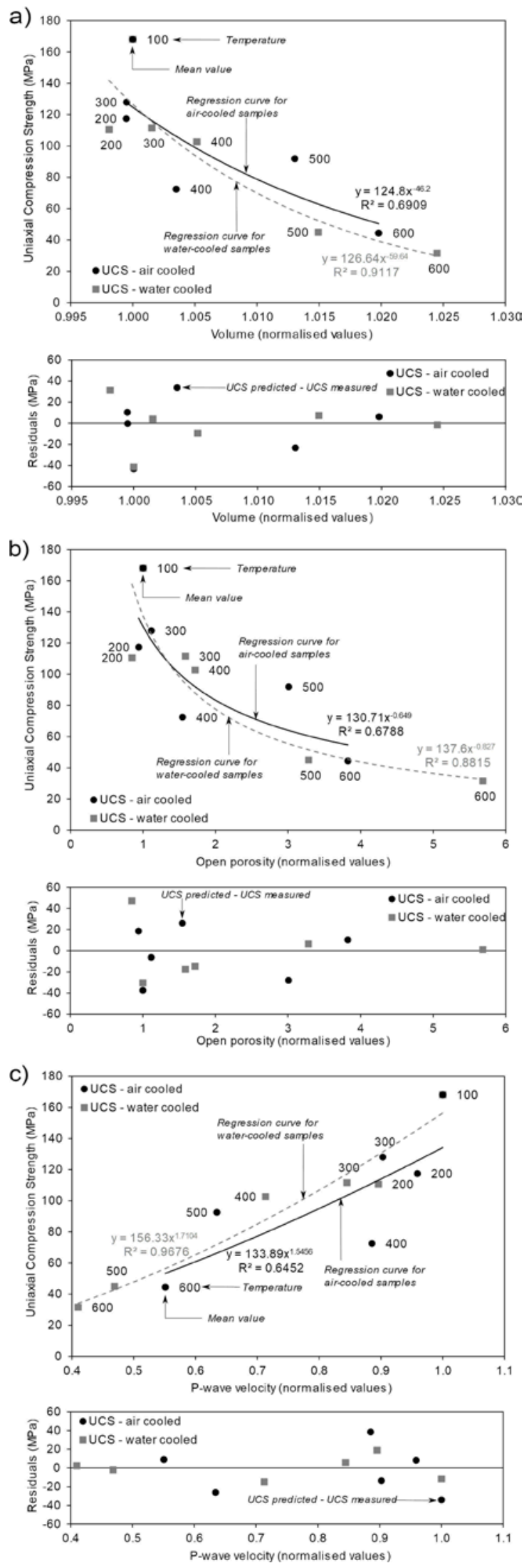

Figure 12. Correlation between UCS and normalised values of volume variation (a), open porosity (b) and P-wave velocity (c) using potential functions. 
a)
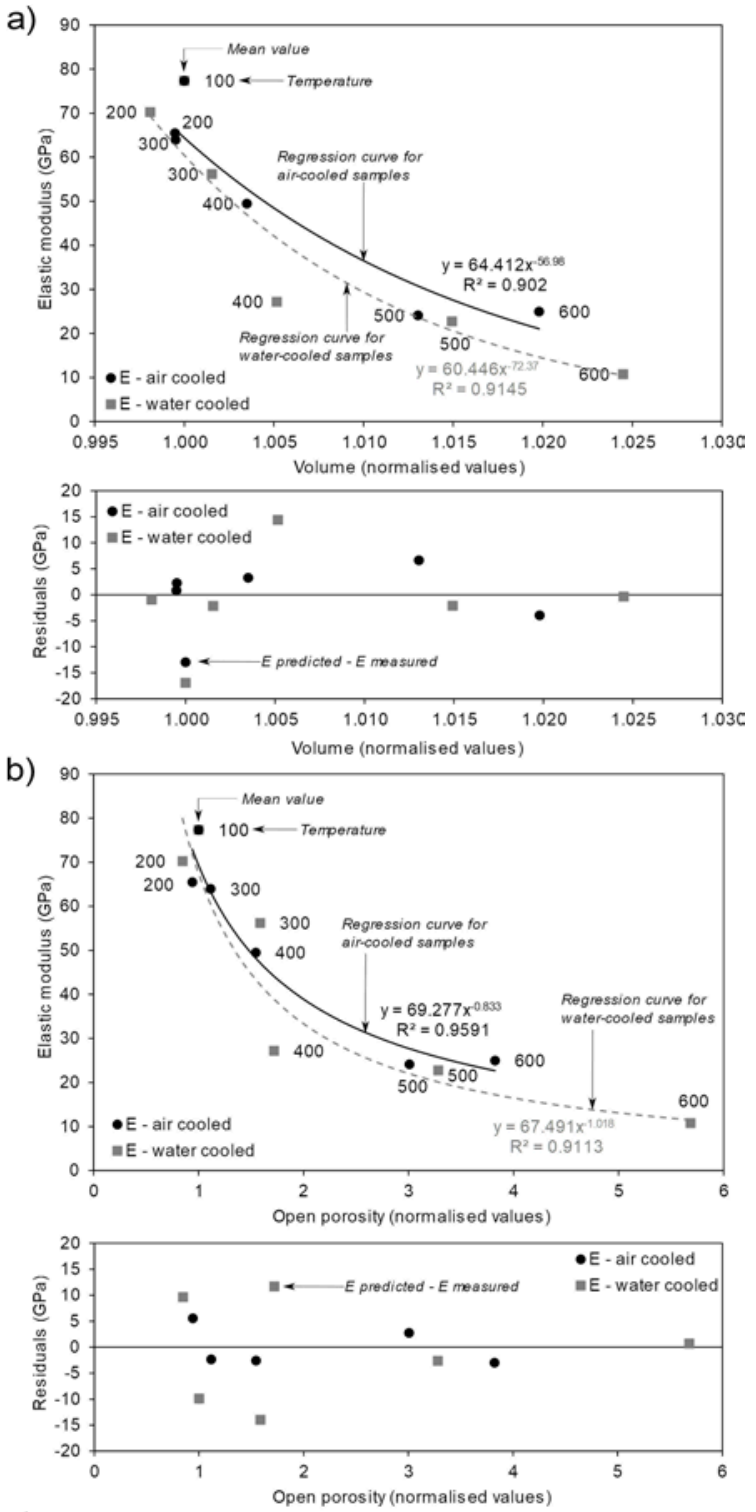

c)
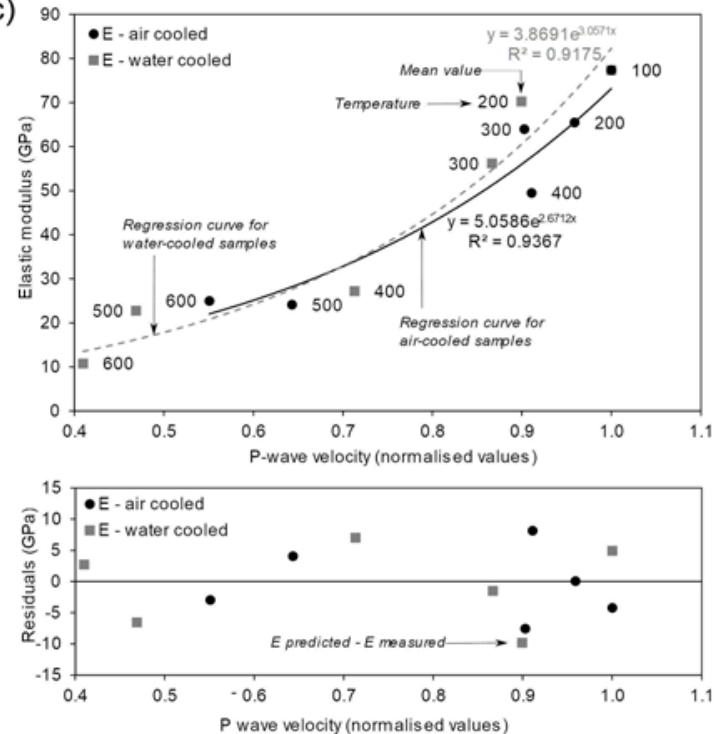

Figure 13. Correlations between static elastic modulus and normalised: (a) volume variation; (b) open porosity; and (c) P-wave velocity. 


\section{Discussion}

Chemical analysis showed that Prada limestone was mainly formed by calcite (92.95\%) and a small fraction of dolomite $(6.11 \%)$. Thermal treatment led to a gradual decomposition of the latter as previously reported by different authors $[21,48]$. Slight or non-perceptible changes in calcite are considered normal for the range of temperatures between 105 and $600^{\circ} \mathrm{C}$, because target temperatures were much lower than that for carbonate dissociation, that exhibit the highest decomposition rate around $700^{\circ} \mathrm{C}$, and is complete near $900^{\circ} \mathrm{C}$ [49]. The content of oxides remained almost unchanged with temperature and showed no clear trend. Thus, different mechanisms seem to be behind the observed variation for Prada limestone. Thermal damage is linked to the anisotropic expansion of calcite, since local thermal stress concentrations occur between mineral particles that lead to microcracking $[16,50]$. The loss of constitution water leads to the destruction of the mineral lattice, causing microstructural changes (including increased porosity) and rock expansion [51]. Such microstructural changes could be directly observed for Prada limestone using SEM and MIP techniques, and the consequent rock expansion was registered in terms of an increase in open porosity and volume.

Although the visual appearance of 'Prada' limestone was very homogeneous, samples presented the slight variations that are typical of such natural materials (including changes in the grey tone and presence of calcite veins) in contrast to manufactured materials whose composition and texture can be controlled. In our study, standard deviation (SD) on UCS for all temperatures was $23.07 \mathrm{MPa}$ with a maximum value of $37.94 \mathrm{MPa}$ at $600^{\circ} \mathrm{C}$. These values are similar to those reported by Sengun [18] (mean SD 25.28 MPa; and maximum SD 31.7 MPa). For elastic modulus, we registered mean SD for all temperatures of $8.21 \mathrm{GPa}$ with a maximum of $13.80 \mathrm{GPa}$ at $400^{\circ}$ $\mathrm{C}$, which are of the same order of magnitude as those obtained by González-Gómez et al. [52] (mean SD $10.17 \mathrm{GPa}$; maximum SD $15 \mathrm{GPa}$ ). We state that accuracy in our results can be considered normal for a natural material such as the studied rock. Trends have been discussed in view of mean values and also considering standard deviation at each temperature. This leads us to make conclusions based on general trends and to dismiss variations based on mean values when SD is high.

Thermal effects on Prada limestone at lower temperatures $\left(105\right.$ to $\left.200^{\circ} \mathrm{C}\right)$ refer to a dramatic drop in UCS of more than $30 \%$ for all cooling methods (Figure 7 ) which were previously reported at low temperatures by Lion et al. (2005). Thus, structural resistance within the Tres Ponts Tunnel may be affected from the initial stages of a fire. A decrease in elastic modulus at $300^{\circ} \mathrm{C}$ coincided with an increase in open porosity for water-cooled samples, and this points to an influence of the cooling method at intermediate temperatures. Furthermore, when open porosity increases, elastic modulus also decreases at $400^{\circ} \mathrm{C}$, as observed for low-porosity limestones (such as Prada) in previous research $[16,18]$. Such variation in open porosity and elastic modulus is explained by means of an expansion of fissures with temperature that leads to a considerable deformation (as observed on stress-strain plots on Figure 8). This is coherent with other works [15,52], and produces a gradual decrease in the elastic modulus [20]. A decrease in ultrasound velocity was registered at $400^{\circ} \mathrm{C}$ due to thermal cracking, as reported for limestone by different authors [1618,53]. This fact is consistent with initial trans-granular fissures and porosity observed using SEM at $400^{\circ} \mathrm{C}$ (Figure $2 \mathrm{~b}$ ). P- and S-wave velocities decrease and elastic modulus drops were greater for water-cooled samples, so the induced micro-structural changes are a function of the maximum temperature as deduced by Crosby et al. [21] and the cooling method. The dynamic elastic modulus trend was similar to that observed for P-and S-wave since ultrasound velocities describe similar trends and dry unit weight showed little variation. It is worth noting that dynamic and static elastic modulus showed similar differences for air- and water-cooling methods for temperatures equal to and greater than $400^{\circ} \mathrm{C}$. The temperature of $500^{\circ} \mathrm{C}$ marked a key point for Prada limestone. Samples showed a sharp increase in open porosity for both cooling methods, as well as a decrease in $\mathrm{P}$ - and S-wave velocities. This threshold temperature also exhibited a significant growth in the density of trans-granular fissures observed by SEM (Figure 2c), as previously reported by Chen et al. [54]. For these reasons, $500^{\circ} \mathrm{C}$ is a threshold temperature from which severe physical damage develops in Prada limestone. Differences induced by the cooling method were perceived for mechanical resistance, since samples cooled by water immersion exhibited a steep drop in the compressive strength of the rock, probably related to the enlargement, coalescence, and connectivity of the trans-granular fissures observed by SEM (Figure 2d) in water-cooled samples. The trends at $600^{\circ} \mathrm{C}$ showed slight variations after the abrupt changes 
observed at up to $500^{\circ} \mathrm{C}$, in agreement with the work published by Zhang et al. [20]. Porosity was an exception and continued exhibiting a significant increases for water-cooled samples. It is remarkable that final values at $600^{\circ} \mathrm{C}$ showed greater variations for water-cooled samples for most parameters, and this indicates greater thermal damage when samples are cooled by water immersion - which is coherent with the results published by Brotóns et al. [11].

A controversial issue arises in the variation of Poisson's ratio for high temperature. Some authors did not report any induced effect of temperature on the rocks $[55,56]$ or describe a decreasing trend $[11,15,20]$. However, Yang et al. [53] suggest that the different instrumental devices, methods, or even the diversity of samples, could lead to such scattered results. This study throws light on this aspect and advances in the analysis of this mechanical parameter using both slow and rapid cooling methods. A continuous decrease in Poisson's ratio can be observed in all cases. This trend is related to a greater transverse ductility in the sample in view of the axial stress-lateral strain curves determined in our study.

The performed ANOVA (Table 4) and simple regression analyses (Figure 11) confirmed the negligible impact of the sample positions (meaning their location in the borehole) in the variability of physical and mechanical properties. As a conclusion, the laboratory results for the different samples can be compared regardless of the borehole from which they were obtained and their location within the borehole. This fact opens the door to the possibility of generalising laboratory results throughout the tunnel to determine variation in mechanical parameters (UCS and elastic modulus) from other physical parameters (normalised volume, open porosity, and P-wave velocity) in the event of a fire. Consequently, simple correlations can be fitted to indirectly obtain reference values for the rock affected by temperature in order to make initial decisions after a fire in the tunnel, since previous experiments show that simple regression can provide good predictions for intact carbonate rocks [34].

In this research, the best predictions were achieved using exponential and potential functions. Focusing on UCS predictions for air-cooled samples, the coefficients of determination varied little depending on the physical property studied (between 0.65 and 0.69 ), that is, fittingquality and average residuals (between 20 and $25 \mathrm{MPa}$ ) were similar for all the predictors studied. Samples cooled with water showed better determination coefficients between 0.88 and 0.97 , the latter being for correlations with P-wave velocity, and average residuals were calculated between 9 and $20 \mathrm{MPa}$, being minimal when using P-wave velocity. Predictions for water-cooled samples were more accurate for the highest temperatures (between 400 and $600^{\circ} \mathrm{C}$ ), with residuals of 6 - $7 \mathrm{MPa}$, with P-wave velocity being the best predictor in the analysis. In the case of elastic modulus predictions, coefficients of determination varied from 0.87 to 0.96 and average residuals for the highest temperatures were calculated between 3 and $6 \mathrm{GPa}$ for all predictors and cooling methods. Predictions of elastic modulus by means of potential and exponential functions were more accurate than those of UCS, with little difference between predictors and cooling methods. The influence in data accuracy has also been evaluated. Predictions of UCS and elastic modulus using normalised volume requires the observation of changes in the third decimal, and the accepted accuracy in volume determination using buoyancy techniques is $0.1 \mathrm{~g}$ [46] and this implies a variation in the fourth decimal in the calculated normalised volume. This makes such correlation little sensitive to the accuracy of the data determination. In the case of predictions made from normalised open porosity, an accuracy of $0.1 \%$ is accepted in open porosity determination [46]. This means that variation in the third decimal could be expected in the normalised values, and so predictions using open porosity would be little sensitive to data accuracy. Accuracy in ultrasound P-wave time is $0.1 \mu \mathrm{s}$, and consequently, variation in the third decimal could be expected in the P-wave normalised values, and so that correlation is insensitive to data accuracy. For all above, such correlations enable predicting mechanical parameters from non-destructive tests on limestone affected by high temperatures.

\section{Conclusions}

In this research, samples from Prada limestone were taken from two horizontal boreholes in the design stage of the Tres Ponts Tunnel. Samples were thermally treated at temperatures of $105,200,300,400,500$ and $600^{\circ} \mathrm{C}$, and subsequently air or water-cooled. Variation in chemical composition and microstructure, as well as physical (open porosity, volume, P- and S-wave 
velocities) and mechanical (uniaxial compressive strength, elastic modulus, and Poisson's ratio) properties were analysed. The following are the primary conclusions:

1. Prada limestone is a rock formed by calcite $(92.95 \%)$ and a small fraction of dolomite $(6.11 \%)$. Thermal cracking is mainly associated with anisotropic expansion of calcite. A clear increase in cracking and porosity with temperature was observed using SEM and MIP and this leads to the loss of physical and mechanical properties.

2. Rocks showed severe weakening in terms of a drop in UCS even at low temperatures $\left(T<200^{\circ} \mathrm{C}\right)$. Therefore, the Tres Ponts Tunnel structure might be threatened in the initial stages of a fire. Thermal damage (open porosity increase, as well as P- and S-wave velocity decay) increased in the range of temperatures between 300 and $400^{\circ} \mathrm{C}$ according to porosity and micro-fissure progression, and damage was greater in water-cooled samples.

3. The temperature threshold of $500^{\circ} \mathrm{C}$ is of paramount importance in Prada limestone and is linked to a dramatic increase in porosity and a decrease in Pand S-wave velocity, and this is associated with the trans-granular fissure progression observed using SEM. Such fissures are larger and more connected in water-cooled samples, which lead to appreciable loss in UCS. Consequently, emergency intervention plans in the Tres Ponts Tunnel should consider such effects when deciding on fire-extinction methods.

4. A final temperature of $600^{\circ} \mathrm{C}$ confirmed greater thermal damage due to watercooling, as values showed greater variation for most parameters. UCS was of above $20 \%$ that for the intact rock and higher temperatures led to samples losing their integrity due to mass cracking.

5. ANOVA and simple regression analyses enabled discarding a significant influence of the natural sample position in the variability of physical and mechanical properties, therefore results can be compared between different samples, and conclusions can be generalised throughout the tunnel.

6. Predictions for elastic modulus were more accurate than those for UCS, with little difference between predictors and cooling methods. Calculated values of UCS after thermal treatment were better for water-cooled samples, especially when using P-wave velocity as a predictor. Exponential and potential functions exhibited best coefficients of determination, are easy to use, and provide quick indicative values to make the initial decisions after a tunnel fire.

This study provides an in-depth insight into the changes induced by temperature in the properties of Prada limestone. The obtained results enable evaluation of the degree of damage and any changes produced in the Tres Ponts Tunnel excavated in this limestone if it is affected by a fire that produces thermal effects.

\section{Acknowledgements}

The authors wish to acknowledge Kreum SA, Ayesa SA, Infraestructures.cat, and the Lleida regional road authority (Servei Territorial de Carreteres de Lleida, Generalitat de Catalunya) for providing rock samples. Isidro Sánchez Martín from the Departamento de Ingeniería Civil of the Universidad de Alicante kindly helped us to analyse the MIP analyses, in addition, Mr. Manuel Ángel Morilla Rubio and Salvatore Di Biase from the Universitat Politècnica de València for their support on laboratory tests. This research was partially supported by the Vice-Rector of Research and Knowledge Transfer at the University of Alicante through projects UAUSTI19-25 and UAUSTI20-20, and by the Departamento de Ingeniería del Terreno at the Universitat Politècnica de València. 


\section{References}

[1] H. Ingason, Fire dynamics in tunnels, in: Handb. Tunn. Fire Saf., ICE Publishing, 2012: pp. 273307. https://doi.org/10.1680/htfs.41530.273.

[2] A. Leitner, The fire catastrophe in the Tauern Tunnel: experience and conclusions for the Austrian guidelines, Tunn. Undergr. Sp. Technol. 16 (2001) 217-223. https://doi.org/10.1016/S08867798(01)00042-6.

[3] PIARC, Experience with significant incidents in road tunnels, 2016. http://www.piarc.org.

[4] ITA, Guidelines for structural fire resistance for road tunnels, 2004. https://doi.org/10.1016/j.tust.2004.01.001.

[5] PIARC, Fire and smoke control in road tunnels, 1999. http://www.piarc.org.

[6] CETU, Comportement au feu des tunnels routiers, Ministère de l'Équipement, des Transports, de l'Aménagement du territoire, du Tourisme et de la Mer. Direction des routes, France, 2005.

[7] A.G. Smith, P.J.N. Pells, Impact of fire on tunnels in Hawkesbury sandstone, Tunn. Undergr. Sp. Technol. 23 (2008) 65-74. https://doi.org/10.1016/j.tust.2006.11.003.

[8] A.G. Smith, P.J. Pells, Discussion of the paper "Impact of fire on Tunnels in Hawkesbury Sandstone" by Smith and Pells [Tunnelling and Underground Space Technology 23 (2008) 65-74], Tunn. Undergr. Sp. Technol. 24 (2009) 112-114. https://doi.org/10.1016/j.tust.2008.05.001.

[9] E. Nordlund, P. Zhang, S. Dineva, C. Saiang, G. Mainali, Impact of fire on the stability of hard rock tunnels in Sweden, Stockholm, $2014 . \quad \mathrm{https}$ ://www.divaportal.org/smash/get/diva2:994806/FULLTEXT01.pdf.

[10] Z. Li, L.N.Y. Wong, C.I. Teh, Low cost colorimetry for assessment of fire damage in rock, Eng. Geol. 228 (2017) 50-60. https://doi.org/10.1016/j.enggeo.2017.07.006.

[11] V. Brotóns, R. Tomás, S. Ivorra, J.C. Alarcón, Temperature influence on the physical and mechanical properties of a porous rock: San Julian's calcarenite, Eng. Geol. 167 (2013) 117-127. https://doi.org/10.1016/j.enggeo.2013.10.012.

[12] M.Y. Koca, G. Ozden, A.B. Yavuz, C. Kincal, T. Onargan, K. Kucuk, Changes in the engineering properties of marble in fire-exposed columns, Int. J. Rock Mech. Min. Sci. 43 (2006) 520-530. https://doi.org/10.1016/j.ijrmms.2005.09.007.

[13] L. Pei, G. Blöcher, H. Milsch, G. Zimmermann, I. Sass, E. Huenges, Thermo-mechanical Properties of Upper Jurassic (Malm) Carbonate Rock Under Drained Conditions, Rock Mech. Rock Eng. 51 (2018) 23-45. https://doi.org/10.1007/s00603-017-1313-0.

[14] C.-L. Zhang, N. Conil, G. Armand, Thermal effects on clay rocks for deep disposal of high-level radioactive waste, J. Rock Mech. Geotech. Eng. 9 (2017) 463-478. https://doi.org/10.1016/j.jrmge.2016.08.006.

[15] M. Lion, F. Skoczylas, B. Ledésert, Effects of heating on the hydraulic and poroelastic properties of bourgogne limestone, Int. J. Rock Mech. Min. Sci. 42 (2005) 508-520. https://doi.org/10.1016/j.ijrmms.2005.01.005.

[16] H. Yavuz, S. Demirdag, S. Caran, Thermal effect on the physical properties of carbonate rocks, Int. J. Rock Mech. Min. Sci. 47 (2010) 94-103. https://doi.org/10.1016/j.ijrmms.2009.09.014.

[17] G.F. Andriani, L. Germinario, Thermal decay of carbonate dimension stones: fabric, physical and mechanical changes, Environ. Earth Sci. 72 (2014) 2523-2539. https://doi.org/10.1007/s12665-0143160-6.

[18] N. Sengun, Influence of thermal damage on the physical and mechanical properties of carbonate rocks, Arab. J. Geosci. 7 (2014) 5543-5551. https://doi.org/10.1007/s12517-013-1177-x.

[19] X.-B. Mao, L. Zhang, T. Li, H. Liu, Properties of failure mode and thermal damage for limestone at 
high temperature, Min. Sci. Technol. 19 (2009) 290-294. https://doi.org/10.1016/S16745264(09)60054-5.

[20] W. Zhang, Q. Sun, S. Zhu, B. Wang, Experimental study on mechanical and porous characteristics of limestone affected by high temperature, Appl. Therm. Eng. 110 (2017) 356-362. https://doi.org/10.1016/j.applthermaleng.2016.08.194.

[21] Z.K. Crosby, P.M. Gullett, S.A. Akers, S.S. Graham, Characterization of the mechanical behavior of salem limestone containing thermally-induced microcracks, Int. J. Rock Mech. Min. Sci. 101 (2018) 54-62. https://doi.org/10.1016/j.jirmms.2017.11.002.

[22] W. Zhang, C. Lv, Effects of mineral content on limestone properties with exposure to different temperatures, J. Pet. Sci. Eng. 188 (2020) 106941. https://doi.org/10.1016/j.petrol.2020.106941.

[23] V.. Singh, D. Singh, T.. Singh, Prediction of strength properties of some schistose rocks from petrographic properties using artificial neural networks, Int. J. Rock Mech. Min. Sci. 38 (2001) 269284. https://doi.org/10.1016/S1365-1609(00)00078-2.

[24] H. Sonmez, E. Tuncay, C. Gokceoglu, Models to predict the uniaxial compressive strength and the modulus of elasticity for Ankara Agglomerate, Int. J. Rock Mech. Min. Sci. 41 (2004) 717-729. https://doi.org/10.1016/j.ijrmms.2004.01.011.

[25] H. Sonmez, C. Gokceoglu, E.W. Medley, E. Tuncay, H.A. Nefeslioglu, Estimating the uniaxial compressive strength of a volcanic bimrock, Int. J. Rock Mech. Min. Sci. 43 (2006) 554-561. https://doi.org/10.1016/j.ijrmms.2005.09.014.

[26] K. Zorlu, C. Gokceoglu, F. Ocakoglu, H.A. Nefeslioglu, S. Acikalin, Prediction of uniaxial compressive strength of sandstones using petrography-based models, Eng. Geol. 96 (2008) 141158. https://doi.org/10.1016/j.enggeo.2007.10.009.

[27] A. Cevik, E.A. Sezer, A.F. Cabalar, C. Gokceoglu, Modeling of the uniaxial compressive strength of some clay-bearing rocks using neural network, Appl. Soft Comput. 11 (2011) 2587-2594. https://doi.org/10.1016/j.asoc.2010.10.008.

[28] C. Gokceoglu, K. Zorlu, A fuzzy model to predict the uniaxial compressive strength and the modulus of elasticity of a problematic rock, Eng. Appl. Artif. Intell. 17 (2004) 61-72. https://doi.org/10.1016/j.engappai.2003.11.006.

[29] L.K. Sharma, V. Vishal, T.N. Singh, Developing novel models using neural networks and fuzzy systems for the prediction of strength of rocks from key geomechanical properties, Measurement. 102 (2017) 158-169. https://doi.org/10.1016/j.measurement.2017.01.043.

[30] D.J. Armaghani, E. Tonnizam Mohamad, E. Momeni, M. Monjezi, M. Sundaram Narayanasamy, Prediction of the strength and elasticity modulus of granite through an expert artificial neural network, Arab. J. Geosci. 9 (2016) 48. https://doi.org/10.1007/s12517-015-2057-3.

[31] R. Singh, R.K. Umrao, M. Ahmad, M.K. Ansari, L.K. Sharma, T.N. Singh, Prediction of geomechanical parameters using soft computing and multiple regression approach, Measurement. 99 (2017) 108-119. https://doi.org/10.1016/j.measurement.2016.12.023.

[32] N. Yesiloglu-Gultekin, C. Gokceoglu, E.A. Sezer, Prediction of uniaxial compressive strength of granitic rocks by various nonlinear tools and comparison of their performances, Int. J. Rock Mech. Min. Sci. 62 (2013) 113-122. https://doi.org/10.1016/j.ijrmms.2013.05.005.

[33] R. Singh, V. Vishal, T.N. Singh, P.G. Ranjith, A comparative study of generalized regression neural network approach and adaptive neuro-fuzzy inference systems for prediction of unconfined compressive strength of rocks, Neural Comput. Appl. 23 (2013) 499-506. https://doi.org/10.1007/s00521-012-0944-z.

[34] E. Yasar, Y. Erdogan, Correlating sound velocity with the density, compressive strength and Young's modulus of carbonate rocks, Int. J. Rock Mech. Min. Sci. 41 (2004) 871-875. https://doi.org/10.1016/j.ijrmms.2004.01.012.

[35] A. Baykasoğlu, H. Güllü, H. Çanakçi, L. Özbakir, Prediction of compressive and tensile strength of limestone via genetic programming, Expert Syst. Appl. 35 (2008) 111-123. 
https://doi.org/10.1016/j.eswa.2007.06.006.

[36] S. Dehghan, G. Sattari, S. Chehreh Chelgani, M. Aliabadi, Prediction of uniaxial compressive strength and modulus of elasticity for Travertine samples using regression and artificial neural networks, Min. Sci. Technol. 20 (2010) 41-46. https://doi.org/10.1016/S1674-5264(09)60158-7.

[37] S. Yagiz, E.A. Sezer, C. Gokceoglu, Artificial neural networks and nonlinear regression techniques to assess the influence of slake durability cycles on the prediction of uniaxial compressive strength and modulus of elasticity for carbonate rocks, Int. J. Numer. Anal. Methods Geomech. 36 (2012) 1636-1650. https://doi.org/10.1002/nag.1066.

[38] S. Aboutaleb, M. Behnia, R. Bagherpour, B. Bluekian, Using non-destructive tests for estimating uniaxial compressive strength and static Young's modulus of carbonate rocks via some modeling techniques, Bull. Eng. Geol. Environ. 77 (2018) 1717-1728. https://doi.org/10.1007/s10064-0171043-2.

[39] P.K. Gautam, A.K. Verma, S. Maheshwar, T.N. Singh, Thermomechanical Analysis of Different Types of Sandstone at Elevated Temperature, Rock Mech. Rock Eng. 49 (2016) 1985-1993. https://doi.org/10.1007/s00603-015-0797-8.

[40] N.N. Sirdesai, A. Singh, L.K. Sharma, R. Singh, T.N. Singh, Development of novel methods to predict the strength properties of thermally treated sandstone using statistical and soft-computing approach, Neural Comput. Appl. 31 (2017) 1-27. https://doi.org/10.1007/s00521-017-3233-z.

[41] N.N. Sirdesai, A. Singh, L.K. Sharma, R. Singh, T.N. Singh, Determination of thermal damage in rock specimen using intelligent techniques, Eng. Geol. 239 (2018) 179-194. https://doi.org/10.1016/j.enggeo.2018.03.027.

[42] J. García Senz, J.A. Muñoz, L. Cabrera, Universitat de Barcelona. Departament de Geodinàmica i Geofísica., Cuencas extensivas del cretácico inferior en los Pirineos centrales, formación y subsecuente inversión, Universitat de Barcelona, 2002.

[43] C. Fairhurst, J.A. Hudson, International society for rock mechanics commission on testing methods, Int. J. Rock Mech. Min. Sci. Geomech. Abstr. 24 (1987) 53. https://doi.org/10.1016/01489062(87)91231-9.

[44] Rabat, R. Tomás, M. Cano, T. Miranda, Impact of water on peak and residual shear strength parameters and triaxial deformability of high-porosity building calcarenite stones: Interconnection with their physical and petrological characteristics, Constr. Build. Mater. 262 (2020) 120789. https://doi.org/10.1016/j.conbuildmat.2020.120789.

[45] Rabat, R. Tomás, M. Cano, Evaluation of mechanical weakening of calcarenite building stones due to environmental relative humidity using the vapour equilibrium technique, Eng. Geol. 278 (2020) 105849. https://doi.org/10.1016/j.enggeo.2020.105849.

[46] J. Franklin, Suggested methods for determining water content, porosity, density absorption and related properties and swelling and slake- durability index properties., Int. J. Rock Mech. Min. Sci. 16 (1979) 141-156.

[47] A. Aydin, Upgraded ISRM suggested method for determining sound velocity by ultrasonic pulse transmission technique, Rock Mech. Rock Eng. 47 (2014) 255-259. https://doi.org/10.1007/s00603013-0454-z.

[48] Q.-B. Meng, C.-K. Wang, J.-F. Liu, M.-W. Zhang, M.-M. Lu, Y. Wu, Physical and micro-structural characteristics of limestone after high temperature exposure, Bull. Eng. Geol. Environ. 79 (2020) 1259-1274. https://doi.org/10.1007/s10064-019-01620-0.

[49] A.M. Ferrero, P. Marini, Technical note: Experimental studies on the mechanical behaviour of two thermal cracked marbles, Rock Mech. Rock Eng. 34 (2001) 57-66. https://doi.org/10.1007/s006030170026.

[50] J. Sippel, S. Siegesmund, T. Weiss, K.-H. Nitsch, M. Korzen, Decay of natural stones caused by fire damage, Geol. Soc. London, Spec. Publ. 271 (2007) 139-151. https://doi.org/10.1144/GSL.SP.2007.271.01.15. 
[51] P.G. Ranjith, D.R. Viete, B.J. Chen, M.S.A. Perera, Transformation plasticity and the effect of temperature on the mechanical behaviour of Hawkesbury sandstone at atmospheric pressure, Eng. Geol. (2012). https://doi.org/10.1016/j.enggeo.2012.09.007.

[52] W.S. González-Gómez, P. Quintana, A. May-Pat, F. Avilés, J. May-Crespo, J.J. Alvarado-Gil, Thermal effects on the physical properties of limestones from the Yucatan Peninsula, Int. J. Rock Mech. Min. Sci. 75 (2015) 182-189. https://doi.org/10.1016/j.jrmms.2014.12.010.

[53] J. Yang, L.-Y. Fu, W. Zhang, Z. Wang, Mechanical property and thermal damage factor of limestone at high temperature, Int. J. Rock Mech. Min. Sci. 117 (2019) 11-19. https://doi.org/10.1016/j.jirmms.2019.03.012.

[54] L. Chen, J. He, J. Chao, B. Qin, Swelling and breaking characteristics of limestone under high temperatures, Min. Sci. Technol. 19 (2009) 503-507. https://doi.org/10.1016/S16745264(09)60094-6.

[55] F.E. Heuze, High-temperature mechanical, physical and Thermal properties of granitic rocks- A review, Int. J. Rock Mech. Min. Sci. Geomech. Abstr. 20 (1983) 3-10. https://doi.org/10.1016/01489062(83)91609-1.

[56] F. Zhang, J. Zhao, D. Hu, F. Skoczylas, J. Shao, Laboratory Investigation on Physical and Mechanical Properties of Granite After Heating and Water-Cooling Treatment, Rock Mech. Rock Eng. 51 (2018) 677-694. https://doi.org/10.1007/s00603-017-1350-8. 